\title{
Improvement of Cold Resistance in Rice Seedlings by 5-Aminolevulinic Acid
}

\author{
Yasushi Hotta, Tohru TanaKa, Luo Bingshan,* \\ Yasutomo TAKEUCHI** and Makoto KONNAI** \\ Cosmo Research Institute, 1134-2 Gongendo, Satte, Saitama 340-0193, Japan \\ *Lab. of Crop Ecophysiology, Huazhong Agricultural University, Wuhan 430070, China \\ **Weed Science Center, Utsunomiya University, 350 Minemachi, Utsunomiya, Tochigi 321-8505, Japan
}

(Received April 3, 1997 ; Accepted October 31, 1997)

\begin{abstract}
5-Aminolevulinic acid (ALA) at low concentrations increased cold resistance in rice seedlings. The pretreatment of rice seedlings by root-soaking with ALA solution at $0.1-1 \mathrm{ppm}$ reduced the ratio of leaf rolling and electrolyte leakage from leaf tissue after cold treatment. Thirty days after cold treatment at $5^{\circ} \mathrm{C}$ for 5 days, the plants treated with 1 ppm ALA resulted in $85 \%$ survival ratio, 6.1 leaves per plant and $111.8 \mathrm{mg}$ dry weight per aerial part of seedling, while $65 \%, 5.9$ and $65.0 \mathrm{mg}$ respectively in the control plants. The dry weight of seedlings treated with ALA increased 1.7 folds as compared to the control plants. These results are the first evidence that ALA has protective effects against cold stress in rice seedlings. Abscisic acid (ABA) and brassinolide (BR) also increased the cold resistance in our bioassay system. Protective effect of BR at $0.001 \mathrm{ppm}$ against cold stress was similar to that of ALA. However, protective effect of ABA was different from that of ALA in terms of the ratio of leaf rolling after cold stress. ABA protected young leaves rather than old ones, while ALA and BR were more effective on the protection of old leaves.
\end{abstract}

\section{INTRODUCTION}

When plants are exposed to cold stress, a variety of biological responses are shown. One of typical responses in some plants sensitive to chilling such as rice, maize and soybean was an apparent decrease of chlorophyll contents when exposed to low temperatures. ${ }^{1)}$ In maize, Hodgins and Huystee showed that one of the damages induced by low temperatures was the decreased 5aminolevulinic acid (ALA) synthesis. Also, when maize plants were grown at $28^{\circ} \mathrm{C}$ and then placed at $12^{\circ} \mathrm{C}$, the porphyrin synthesis was immediately damaged. ${ }^{2-4)}$

We have recently found that ALA, the key precursor in the biosynthesis of porphyrins, increased plant growth and yield at low concentrations, i.e., less than $1.8 \mathrm{mM}$ (300 ppm) by foliar treatment, and less than $60 \mu \mathrm{M}(10$ ppm) by root-soaking treatment. ${ }^{5,6)}$ In rice seedlings, ALA at $0.1-1.0 \mathrm{ppm}$ by root-soaking treatment increased the dry weight of seedlings to $111-114 \% .^{5)}$ These promotive effects may be induced through the increased chlorophyll content, enhanced photosynthetic activity, and the inhibition of respiration by ALA treatment. ${ }^{7)}$

Therefore, we examined whether ALA increased cold resistance and prevented cold injury in rice seedlings. Protective effects of abscisic acid (ABA) and brassinolide
(BR) against cold stress are also reported.

\section{MATERIALS AND METHODS}

\section{Plant Materials}

Seeds of Oryza sativa L. cv AKINISHIKI were sterilized with 200-fold diluted Benlate $\mathrm{T}^{\circledR}$ (active ingredient is benomyl by Du Pont) for $24 \mathrm{~h}$, and washed with distilled water. The seeds were incubated in a plastic container at $30^{\circ} \mathrm{C}$ for 3 days. The germinated seeds were sown in pots filled with paddy soil and were grown in a greenhouse maintained at $27^{\circ} \mathrm{C}$ in the daytime and $18^{\circ} \mathrm{C}$ in the night.

\section{Cold Treatment}

The seedlings at 3-leaf stage were carefully removed from soil, washed, and then the roots of seedlings were immersed for $24 \mathrm{~h}$ in an aqueous solution containing ALA $(0,0.1,1.0$ and $5.0 \mathrm{ppm})$, BR $(0.001 \mathrm{ppm})$, or ABA $(1.0 \mathrm{ppm})$. They were then transplanted to pots (surface area $400 \mathrm{~cm}^{2}$ ) filled with paddy soil. The seedlings were grown in an incubator maintained at $3 \pm 1.5^{\circ} \mathrm{C}$ for 2 or 4 days under light level of $130 \mu \mathrm{mol} / \mathrm{m}^{2} / \mathrm{s}$ and then at $23 \pm$ $3^{\circ} \mathrm{C}$ for 5 days. The cold injury was determined by visual observation in terms of the ratio of leaf rolling immediately after cold treatment and after the subsequent 
incubation at $23 \pm 3^{\circ} \mathrm{C}$ for 5 days. A visual scoring of leaf rolling from the base was done by counting the number of rolled leaf blades before and after the test. In another experiment, the seedlings were grown at $5 \pm 1.5^{\circ} \mathrm{C}$ for 1 day or 5 days and then at $23 \pm 3^{\circ} \mathrm{C}$ for 30 days. The ratio of leaf rolling immediately after cold treatment was determined to cold stress at $5 \pm 1.5^{\circ} \mathrm{C}$ for 5 days. The growth of seedlings incubated at $23 \pm 3^{\circ} \mathrm{C}$ for 30 days was evaluated in terms of the survival ratio of plants, the number of leaves and the dry weight per aerial part of seedling.

\section{Electrolyte Leakage from Chilled Leaves}

The roots of seedlings at 3-leaf stage were soaked in the test solutions for $24 \mathrm{~h}$, and then the seedlings were grown in pots at $3 \pm 1.5^{\circ} \mathrm{C}$ for 1,3 , or 5 days. After cold treatment, the leaf blades of seedlings were cut into $1 \mathrm{~cm}$ long segments. Six segments of the blades were put into each plastic cup containing $15 \mathrm{ml}$ of deionized water, and the cups were shaken gently at $25^{\circ} \mathrm{C}$ for $4 \mathrm{~h}$ in darkness. The electric conductivity of the solutions was measured by a conductivity meter. The degree of electrolyte leakage was calculated by the relative percentage against the conductivity of the segments that were frozen at $-20^{\circ} \mathrm{C}$ and thawed at $25^{\circ} \mathrm{C}$.

\section{RESULTS}

\section{Ratio of Leaf Rolling in Rice Seedlings Immediately after Cold Treatment}

The effects of ALA on cold resistance were evaluated in terms of the ratio of leaf rolling of rice seedlings. The roots of seedlings were soaked in the test solutions for 24 $\mathrm{h}$, and then the treated plants were grown at $3 \pm 1.5^{\circ} \mathrm{C}$ for 2 or 4 days. ALA pretreatment at 0.1 and $1 \mathrm{ppm}$, but not at $5 \mathrm{ppm}$, reduced the ratio of leaf rolling of the first leaf blades when evaluated immediately after cold treatment (Table 1). The ratios of leaf rolling in the seedlings treated with 0 (control), 0.1 , and 1 ppm ALA were $50.0,21.7$ and $23.3 \%$ respectively after cold treatment for 2 days, and 56.7, 35.0 and $35.0 \%$ respectively after cold treatment for 4 days. However, ALA did not affect the ratio of leaf rolling of the 2 nd and the 3 rd leaf blades.
Pretreatment with BR at $0.001 \mathrm{ppm}$ also reduced the ratio of leaf rolling of the first leaf blades, and the ratios were 15.0 and $31.7 \%$ after cold treatment for 2 days and 4 days, respectively. BR had no effects on the ratio of leaf rolling of the 2 nd and the 3 rd leaf blades. On the other hand, pretreatment with $\mathrm{ABA}$ at $1 \mathrm{ppm}$ affected the ratio of leaf rolling of the first and the 2 nd leaf blades of seedlings, and the ratios of leaf rolling of the first and the 2nd leaf blades subjected to cold treatment for 2 days and 4 days were 31.7 and $78.3 \%, 45.0$ and $81.7 \%$, respectively.

Effects on cold treatment at $5 \pm 1.5^{\circ} \mathrm{C}$ for 5 days were also examined (Table 1). The ratios of leaf rolling of the first and the 2nd leaf blades in the control (water) were 71.4 and $96.4 \%$. In rice seedlings treated with 0.1 ppm ALA, 1 ppm ALA and 0.001 ppm BR, the ratios of leaf rolling of the first and the 2 nd leaf blades were 53.8, 50.0 and $48.0 \%$, and $88.5,44.2$ and $84.0 \%$, respectively.

Ratio of Leaf Rolling in Rice Seedlings Grown for 5 Days after Cold Treatment

The plants treated with the test solutions were grown at $3 \pm 1.5^{\circ} \mathrm{C}$ for 4 days and then at $23 \pm 3^{\circ} \mathrm{C}$ for 5 days. The rolling of chilled leaves was partially recovered when the seedlings were transferred to warming conditions. So, the ratio of leaf rolling was decreased as compared to the results shown in Table 1. The ratios of the first and the 2nd leaf blades in the control (water) were 38.5 and $81.7 \%$. In rice seedlings treated with $0.1 \mathrm{ppm}$ ALA, 1 ppm ALA and $0.001 \mathrm{ppm}$ BR, the ratios of leaf rolling of the first and the 2nd leaf blades were 11.7, 25.0 and 18.3\%, and $65.0,60.0$ and $71.7 \%$, respectively (Table 2). However ALA at $5 \mathrm{ppm}$ had no effects on the ratio of leaf rolling of the first and the 2 nd leaf blades. Protective effect of ABA was different from those of ALA and BR, and the first leaf blades of the seedlings treated with ABA at $1 \mathrm{ppm}$ were completely rolled. By contrast, the ratios of leaf rolling of the 2 nd and the 3rd leaf blades in the ABA-treated seedlings were 28.3 and $30.0 \%$, respectively. Therefore, protective effect of ABA was more apparent in younger leaves than in older ones.

Table 1 Ratio of leaf rolling of rice seedlings immediately after cold treatment.

\begin{tabular}{|c|c|c|c|c|c|c|c|}
\hline \multirow{2}{*}{\multicolumn{2}{|c|}{$\begin{array}{r}\text { Cold treatment } \\
(\mathrm{ppm})\end{array}$}} & \multicolumn{2}{|c|}{$\begin{array}{c}\text { For } 2 \text { days at } 3 \pm 1.5^{\circ} \mathrm{C} \\
\text { Leaf rolling }(\%)\end{array}$} & \multicolumn{2}{|c|}{$\begin{array}{c}\text { For } 4 \text { days at } 3 \pm 1.5^{\circ} \mathrm{C} \\
\text { Leaf rolling }(\%)\end{array}$} & \multicolumn{2}{|c|}{$\begin{array}{c}\text { For } 5 \text { days at } 3 \pm 1.5^{\circ} \mathrm{C} \\
\text { Leaf rolling (\%) }\end{array}$} \\
\hline & & First leaf & 2nd leaf & First leaf & 2nd leaf & First leaf & 2nd leaf \\
\hline Control & - & $50.0 \pm 10.8$ & 100 & $56.7 \pm 8.5$ & 100 & $71.4 \pm 5.2$ & $96.4 \pm 2.0$ \\
\hline \multirow[t]{3}{*}{ ALA } & 0.1 & $21.7 \pm 2.4$ & 100 & $35.0 \pm 4.1$ & 100 & $53.8 \pm 4.0$ & $88.5 \pm 2.3$ \\
\hline & 1.0 & $23.3 \pm 3.5$ & $96.7 \pm 4.7$ & $35.0 \pm 8.2$ & 100 & $50.0 \pm 3.8$ & $44.2 \pm 5.4$ \\
\hline & 5.0 & $46.7 \pm 6.2$ & 100 & $60.0 \pm 4.1$ & 100 & & \\
\hline BR & 0.001 & $15.0 \pm 4.1$ & 100 & $31.7 \pm 13.1$ & 100 & $48.0 \pm 8.9$ & $84.0 \pm 3.1$ \\
\hline ABA & 1.0 & $31.7 \pm 13.1$ & $78.3 \pm 6.2$ & $45.0 \pm 7.1$ & $81.7 \pm 2.4$ & & \\
\hline
\end{tabular}

Data are means $\pm S E$ of 32 plants. 


\section{Electrolyte Leakage from Rice Seedlings}

Electrolyte leakage has widely been used as an index of cold injury. A rapid increase in electrolyte leakage was observed during prolonged exposure of rice seedlings to the low temperature (Fig. 1). ALA treatment reduced electrolyte leakage from leaf tissue caused by cold treatment. But the reduction of electrolyte leakage after ALA treatment did not proportionally correlate with concentrations of ALA. At the end of cold treatment for 5 days, electrolyte leakage in the control plot was

Table 2 Ratio of leaf rolling of rice seedlings incubated at $3 \pm 1.5^{\circ} \mathrm{C}$ for 4 days and then at $23 \pm 3^{\circ} \mathrm{C}$ for 5 days.

\begin{tabular}{lrccc}
\hline & \multicolumn{3}{c}{ Leaf rolling (\%) } \\
& $(\mathrm{ppm})$ & First leaf & 2nd leaf & 3rd leaf \\
\hline Control & - & $38.5 \pm 5.5$ & $81.7 \pm 4.7$ & 100 \\
ALA & 0.1 & $11.7 \pm 2.4$ & $65.0 \pm 4.1$ & 100 \\
& 1.0 & $25.0 \pm 4.1$ & $60.0 \pm 4.3$ & 100 \\
& 5.0 & $40.0 \pm 14.2$ & $81.7 \pm 8.5$ & 100 \\
BR & 0.001 & $18.3 \pm 14.3$ & $71.7 \pm 8.5$ & 100 \\
ABA & 1.0 & 100 & $28.3 \pm 13.1$ & $30.0 \pm 14.2$ \\
\hline
\end{tabular}

Data are means \pm SE of 32 plants.

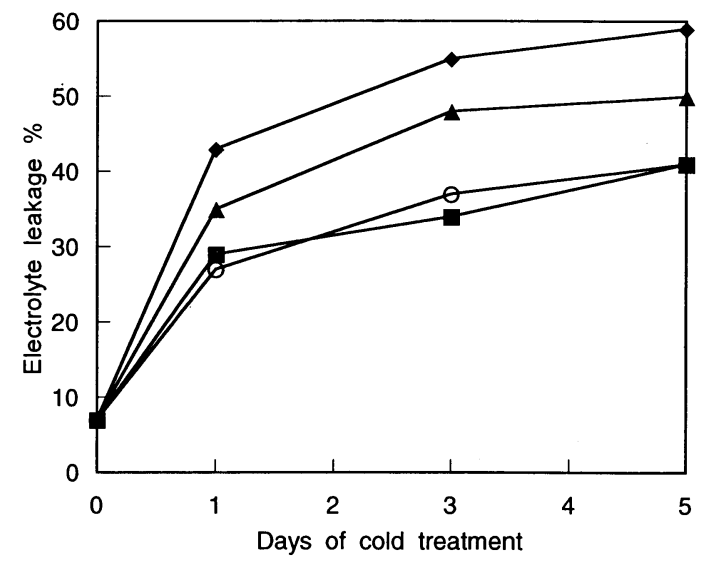

Fig. 1 Effect of ALA concentration on electrolyte leakage from the chilled leaf tissues.

$\checkmark$ : non-treatment, $\mathbf{\square}$ : ALA $0.1 \mathrm{ppm}, \bigcirc$ : ALA $1 \mathrm{ppm}, \boldsymbol{\Delta}$ : ALA 5 ppm.
$59 \%$, and those in the plots treated with ALA at $0.1,1$, and $5 \mathrm{ppm}$ were 40,41 and $51 \%$, respectively.

Treatment with BR at $0.001 \mathrm{ppm}$ resulted in $44 \%$ electrolyte leakage and thus its protective effect was similar to that of ALA. Treatment with ABA at $1 \mathrm{ppm}$ minimized the electrolyte leakage and resulted in $24 \%$ electrolyte leakage at the end of the cold treatment (Fig. 2).

\section{Recovery Growth of the Rice Seedlings after Cold Stress}

Effects of ALA and BR on a recovery growth of the seedlings after cold stress were evaluated by incubating the seedlings at $23 \pm 3^{\circ} \mathrm{C}$ for 30 days after cold treatment at $5 \pm 1.5^{\circ} \mathrm{C}$ for 1 or 5 days (Table 3 ). The seedlings that had been exposed to cold stress at $5 \pm 1.5^{\circ} \mathrm{C}$ for 5 days were more severely damaged than those exposed for 1 day. In the test of cold treatment for 1 day, ALA at 1 ppm increased the survival ratio of plant $(90 \%)$ and the dry weight per aerial part of seedling $(279.9 \mathrm{mg})$ as compared to the control plants, $80 \%$ and $193 \mathrm{mg}$ respectively. In the test of cold treatment for 5 day, treatment with ALA at $1 \mathrm{ppm}$ increased the survival ratio of plant (85\%) and the dry weight per aerial part of seedling

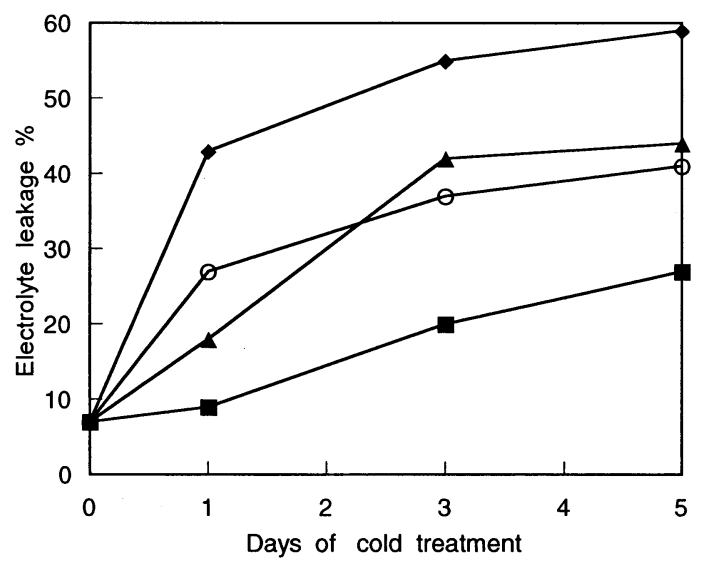

Fig. 2 Effect of ALA, BR and ABA on electrolyte leakage from the chilled leaf tissues.

$\checkmark$ : non-treatment, $\bigcirc$ : ALA 1 ppm, $\Delta$ : BR $0.001 \mathrm{ppm}$, ABA 1 ppm.

Table 3 Survival ratio, number of leaves and dry weight of aerial part per plant of rice seedlings incubated at $5 \pm 1.5^{\circ} \mathrm{C}$ for 5 days and then at $23 \pm 3^{\circ} \mathrm{C}$ for 30 days.

\begin{tabular}{|c|c|c|c|c|c|c|c|}
\hline \multicolumn{2}{|c|}{ Cold treatment } & \multicolumn{3}{|c|}{ For 1 days at $5 \pm 1.5^{\circ} \mathrm{C}$} & \multicolumn{3}{|c|}{ For 5 days at $5 \pm 1.5^{\circ} \mathrm{C}$} \\
\hline & (ppm) & $\begin{array}{l}\text { Survival } \\
\text { ratio (\%) }\end{array}$ & $\begin{array}{l}\text { Leaves } \\
\text { /plant }\end{array}$ & $\begin{array}{l}\text { Dry weight } \\
\text { (mg/plant) }\end{array}$ & $\begin{array}{l}\text { Survival } \\
\text { ratio (\%) }\end{array}$ & $\begin{array}{l}\text { Leaves } \\
\text { /plant }\end{array}$ & $\begin{array}{l}\text { Dry weight } \\
\text { (mg/plant) }\end{array}$ \\
\hline Control & - & 85 & 6.7 & 193.0 & 65 & 5.9 & 65.0 \\
\hline \multirow[t]{2}{*}{ ALA } & 0.1 & 90 & 6.9 & 243.2 & 75 & 6.0 & 81.9 \\
\hline & 1.0 & 90 & 6.9 & 279.9 & 85 & 6.1 & 111.8 \\
\hline BR & 0.001 & - & - & - & 90 & 6.0 & 87.1 \\
\hline
\end{tabular}

Data are means of 32 plants. 
$(111.8 \mathrm{mg})$ as compared to the control plants, $65 \%$ and $65.0 \mathrm{mg}$, respectively. Therefore, treatment with ALA at $1 \mathrm{ppm}$ was more effective than that at $0.1 \mathrm{ppm}$. BR at $0.001 \mathrm{ppm}$ also increased the survival ratio of plant (90\%) and the dry weight per aerial part of seedling $(87.1 \mathrm{mg})$, but its effect on the dry weight basis was smaller than that of ALA.

\section{DISCUSSION}

Rice at the seedling stage frequently confronts cold damage in early spring in the field, and this results in a severe growth retardation. Therefore, we examined the effect of ALA on cold resistance in rice seedlings.

The seedlings treated with ALA at low concentrations showed a reduced ratio of leaf rolling after cold treatment (Tables 1 and 2). ALA also reduced electrolyte leakage from leaf tissue caused by cold injuries (Fig. 1). The effects of ALA depended on its concentrations and the conditions of cold stress. Regarding effective concentrations of ALA, an optimal ALA concentration for protective effect in the electrolyte leakage test was similar to that in the leaf rolling test, being in the range $0.1-1 \mathrm{ppm}$. Further increase in ALA concentration seems to decrease the protective effect.

The effects of cold stress on rice seedlings varied with conditions of cold treatment. The 2 nd and the 3 rd leaf blades of rice seedlings were completely rolled after cold treatment at $3 \pm 1.5^{\circ} \mathrm{C}$ for 2 or 4 days (Table 1). The rolling of the 3rd leaves of the chilled seedlings was not recovered during the subsequent incubation at $23 \pm 3^{\circ} \mathrm{C}$ for 5 days (Table 2). Furthermore, the seedlings exposed to cold stress at $3 \pm 1.5^{\circ} \mathrm{C}$ for 4 days did not grow normally during the subsequent incubation at $23 \pm 3^{\circ} \mathrm{C}$ for 30 days. In contrast, the ratio of leaf rolling of the 2nd leaf blades in rice seedlings which had been exposed to cold stress at $5 \pm 1.5^{\circ} \mathrm{C}$ for 5 days was decreased by ALA treatment. Therefore, the effect of ALA on the recovery from cold damage was evaluated for rice seedlings which had been exposed to cold stress at $5 \pm 1.5^{\circ} \mathrm{C}$.

In the recovery growth of seedlings after cold stress, ALA greatly enhanced the growth of plants which were incubated at $23 \pm 3^{\circ} \mathrm{C}$ for 30 days. In particular, the dry weight of seedlings increased $1.4-1.7$ folds as compared to the control plants (Table 3). The appropriate concentration of ALA on a root soaking treatment may be 1 ppm. These results are consistent with our earlier findings that ALA increased the growth of rice seedlings at ambient temperature. ${ }^{5)}$

These results suggest that ALA may be effective for the recovery from the cold injury rather than for protection against cold stress. The protective effects of ALA against cold stress may be related to its plant growth regulating properties, such as an enhancement of plant growth, photosynthesis and chlorophyll biosynthesis. ${ }^{7)}$

The promotive effects of brassinosteroids including BR on plant growth have been evaluated in several bioassays. However, only a few studies on the anti-stress effect of brassinosteroids in plants have been reported. Mandava showed that brassinosteroids helped to overcome stresses exerted by low and high temperatures, drought, infection and agricultural chemicals. ${ }^{8)}$ In addition, rice plants treated with brassinosteroids grew better than control plants under low temperature conditions. ${ }^{9)}$ In our bioassay system, BR also improved the damage caused by cold stress. Protective effects of BR in terms of the ratio of leaf rolling (Tables 1 and 2) and the reduction of electrolyte leakage (Fig. 2) were similar to those of ALA. In the recovery growth of seedlings after cold stress, BR promoted the growth of plants during the incubation at $23 \pm 3^{\circ} \mathrm{C}$ for 30 days, but its effect on the dry weight basis was less than that of ALA (Table 3). An influence of brassinosteroids on the growth recovery of maize and cucumber seedlings after cold stress has also been reported. ${ }^{10)}$

ABA was suggested to be a stress hormone and related closely to the adaptation of plants to stressful conditions. ${ }^{1-15)}$ It was known that $\mathrm{ABA}$ treatment before cold stress ameliorated cold injury of rice seedlings. ${ }^{16,17)}$ There was also a reported attempt to protect rice plants against the cold stress using an ABA analogue. ${ }^{18)}$ In addition, it was shown that endogenous ABA levels were higher in cold-tolerant rice seedlings than in cold-sensitive rice seedlings after exposure to low temperatures. ${ }^{19,20)}$ Our results also demonstrated that ABA reduced the ratio of leaf rolling (Tables 1 and 2) and the electrolyte leakage (Fig. 2). However, mechanisms involved in the protection from cold injury might be different between $\mathrm{ABA}$ and ALA or BR, since $\mathrm{ABA}$ protected young leaves rather than old ones, while ALA and BR were more effective on the protection of old leaves. Furthermore, the effects of ALA and BR on the reduction of electrolyte leakage were weaker than that of ABA.

The relations between cold tolerance and plant dry matter percentage, ${ }^{21)}$ carbohydrate content, ${ }^{22)}$ phospholipid content, ${ }^{23)}$ amino acid content, ${ }^{24)}$ unsaturated fatty acids of membrane lipids ${ }^{25}$ and heat-stable proteins $^{26)}$ have been studied. In rice plants, one of the possible functions of $\mathrm{ABA}$ in ameliorating cold injury was proposed to be the maintenance of water balance by regulating stomatal movement ${ }^{19,27)}$ and increasing root hydraulic conductivity. ${ }^{16)}$ The effect of ABA on the reduction of electrolyte leakage in rice seedlings was due to increased polyamine levels. ${ }^{20}$ In mung bean leaves pretreated with an $\mathrm{ABA}$ analogue, the reduction of electrolyte leakage was due to minimized leakage of soluble carbohydrates and free amino acids ${ }^{28}$.

Our results suggest that ALA improves the injury caused by cold stress. In particular, the dry weight of ALA-treated seedlings increased 1.4-1.7 folds as compar- 
ed to the control plants in the recovery growth after cold stress. However, the factors contributing to cold tolerance have not clearly been established. Further studies are needed to understand the physiological functions affected by ALA, in particular, those involved in the protection against cold stress.

\section{REFERENCES}

1) T. Alberta : Acta Bot. Neerl. 18, 39 (1969)

2) R. R. Hodgins \& R. B. van Huystee: Can. J. Bot. 63, 711 (1985)

3) R. R. Hodgins \& R. B. van Huystee : J. Plant Physiol. 125, 325 (1986)

4) R. R. Hodgins \& R. B. van Huystee : J. Plant Physiol. 126, 257 (1986)

5) Y. Hotta, K. Watanabe, T. Tanaka, Y. Takeuchi \& M. Konnai : J. Pesticide Sci. 22, 102 (1997) (in Japanese)

6) Y. Hotta, T. Tanaka, H. Takaoka, Y. Takeuchi \& M. Konnai : Plant Growth Regul. 22, 109 (1997)

7) Y. Hotta, T. Tanaka, H. Takaoka, Y. Takeuchi \& M. Konnai : Biosci. Biotech. Biochem. 61, 2025 (1997)

8) N. B. Mandava: Annu. Rev. Plant Physiol. Plant Mol. Biol. 39, 23 (1988)

9) Y. Kamuro \& S. Takatsuto: "Brassinosteroids : Chemistry, Bioactivity and Applications," ACS Symposium, Ser. 474, ed. by H. G. Cutler, T. Yokota and G. Adam, American Chemical Society, Washington, DC, pp. 292-297, 1991

10) R. Y. He, G. J. Wang \& X. S. Wang: "Brassinosteroids : Chemistry, Bioactivity and Applications," ACS Symposium, Ser. 474, ed. by H. G. Cutler, T. Yokota and G. Adam, American Chemical Society, Washington, DC, pp. 220-230, 1991

11) A. Rikin, M. Maldman, A. E. Richmond \& A. Dovrat: $J$. Exp. Bot. 26, 175 (1975)

12) C. N. Keith \& B. D. McKersie: Plant Physiol. 80, 766 (1986)

13) A. J. Robertson \& L. B. Gusta : Can. J. Bot. 64, 2758 (1986)

14) A. J. D. Zeevaart \& R. A. Creelman: Annu. Rev. Plant Physiol. Plant Mol. Biol. 39, 439 (1988)

15) A. M. Hetherington \& R. S. Quatrano: New Phytol. 119, 9 (1991)

16) N. Kabaki \& K. Tajima : Jpn. J. Crop. Sci. 50, 489 (1981)

17) A. A. Flores-Nimedez, K. Dorffling \& B. S. Vergara :
IRRN 15: 2, 19 (1990)

18) A. A. Flores-Nimedez, K. Dorffling \& B. S. Vergara : J. Plant Growth Regul. 12, 27 (1993)

19) T. M. Lee, H. S. Lur \& C. Chu : Plant Cell Environ. 16, 481 (1993)

20) T. M. Lee, H. S. Lur \& C. Chu : Crop Sci. 35, 502 (1995)

21) A. L. Brule-Babel \& D. B. Fowler : Can. J. Plant Sci. 69, 555 (1989)

22) D. P. Livingston, C. R. Olien \& R. D. Freed : Crop Sci. 29, 1266 (1989)

23) E. J. Kendall \& B. D. McKersie: Physiol. Plant 76, 86 (1989)

24) R.M.M. Crawford : "Studies in Ecology," Vol. 2, Blackwell Scientific, Palo Alto, California, pp. 22-31, 1989

25) I. Nishizawa \& N. Murata : Annu. Rev. Plant Physiol. Plant Mol. Biol. 47, 541 (1995)

26) T. J. Close, A. A. Kortt \& P. M. Chandler : Plant Mol. Biol. 13, 95 (1989)

27) D. Emaus, R. Fenton \& J. M. Wilson : J. Exp. Bot. 34, 434 (1983)

28) Y. Y. Chen \& C. H. Lin : J. Plant Growth Regul. 12, 51 (1993)

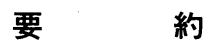

\section{5-アミノレブリン酸によるイネ苗の耐寒性向上}

堀田康司, 田中 徹, 駱 炳山, 竹内安智, 近内誠登 イネ苗の耐寒性に対する5-アミノレブリン酸 (ALA) の 作用を検討した。 0.1-1 ppmの ALA 水溶液に根を浸漬した 場合, 低温処理後のイネ苗において, ALA は葉身への低温 傷害（Leaf rolling）を減少させた．また葉身からの電解質 の漏出も減少させた。同濃度の ALA を前処理したイネ苗 を $5^{\circ} \mathrm{C}, 5$ 日間低温処理し, その後に常温で 30 日間栽培し た場合, ALA はイネ苗の生存率を高め, 乾燥重量を無処理 区の約 1.4-1.7 倍に増加させた。また，その適正濃度は 1 ppm であった. ブラシノライド (BR) は, イネ苗葉身の Leaf rolling 及び電解質の漏出において ALA と類似した作用を 示したが，低温処理後の回復成長において ALAよりも効 果が小さかった。アブシジン酸 (ABA) は，低温処理後の Leaf rolling の結果から，その作用が ALA 及び BR の作用 と異なることが示唆された。 寸なわち, ALA 及びBR は古 い葉に，ABA は若い葉に対してより強い作用を示した。 